\title{
New records and taxonomic notes on Cryphalus Erichson, 1836 in Hawai'i (Coleoptera: Curculionidae: Scolytinae)
}

\author{
ANDREW J. JOHNSON ${ }^{*}$, DAVID HONSBERGER ${ }^{2} \&$ ROGER A. BEAVER 3 \\ ${ }^{1}$ School of Forest, Fisheries, and Geomatics Sciences, University of Florida, Gainesville, Florida 32611. \\ ${ }^{2}$ Entomology Section, Department of Plant and Environmental Protection Sciences, College of Tropical Agriculture and Human Re- \\ sources, University of Hawai 'i at Mānoa, 3050 Maile Way, Honolulu, Hawai 'i 96822, U.S.A. \\ ఏ”dnh8@hawaii.edu; ○ https://orcid.org/0000-0002-3656-7258 \\ ${ }^{3}$ 161/2 Mu 5, Soi Wat Pranon, T. Donkaew, A. Maerim, Chiangmai 50180, Thailand. \\ ”=rogerbeaver6@gmail.com; ㄴ https://orcid.org/0000-0003-1932-3208

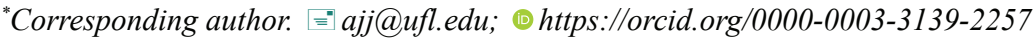

\begin{abstract}
We review the taxonomy and provide identification resources for the species of Cryphalus Erichson, 1836 from the Hawaiian Islands. Five species are present, Cryphalus brasiliensis (Schedl, 1976) new country record, Cryphalus mangiferae Stebbing, 1914, Cryphalus negrosensis Browne, 1979, Cryphalus sylvicola (Perkins, 1900), and Cryphalus trypanoides (Beeson, 1935) (= Cryphalus mollis Schedl, 1955 syn. nov.). Additionally, while reviewing the species, two species not present in Hawai'i are resurrected from synonymy with C. sylvicola: Cryphalus pini (Hopkins, 1915) stat. res. and Cryphalus swezeyi (Schedl, 1942) stat. res. None of the Hawaiian species are endemic, and most are known from most major Pacific islands, and presumed introduced. Cryphalus negrosensis is a likely recent introduction and is a frugivorous scolytine, collected from a wide range of fruits, and found breeding in Artocarpus altilis fruit pulp.
\end{abstract}

Key words: bark beetles, taxonomy, new synonymy, exotic, adventive, pacific islands, breadfruit

\section{Introduction}

Bark and ambrosia beetles (Scolytinae) are present in almost every area with trees. The Pacific islands have some of the better understood communities, with much attention given to the description of their diversity, especially in the $20^{\text {th }}$ century (e.g. Perkins 1900; Beeson 1935; Schedl 1941; Beaver 1976; Beaver \& Maddison 1990). In Hawai‘i, however, some bark beetles have been neglected from recent study. One such group is Cryphalus Erichson, 1836, for which there are no recent publications which treat or describe the species from Hawai'i. There are occasional publications which include records with taxonomic identities that were uncertain at the time (e.g. Bernard et al. 2018) or unconfirmed, or just list species mentioned in the literature without citing specimens (e.g. Nishida 2002). In combination with the taxonomic confusion, there are no guides to accurately diagnose the species present in Hawai'i.

This review assesses the species present based on historic samples and new collections, reviews the diagnostic characters, the distribution, and the host range of the species present in the Hawaiian Islands, and provides photographs and a key to enable identification of specimens.

\section{Materials and methods}

Most of the specimens used in this study were collected by the dissection of plant material found to be inhabited by scolytines. Vouchers from the same collection are deposited in UHIM (University of Hawai'i Insect Museum, Honolulu, Hawai'i), BPBM (Bernice P. Bishop Museum, Honolulu, Hawai'i), HDOA (Hawai'i Department of Agriculture, Honolulu, Hawai 'i), FSCA (Florida State Collection of Arthropods, Gainesville, Florida, USA), USNM 
(National Museum of Natural History, Washington D.C.), and UFFE (University of Florida Forest Entomology collection, Gainesville, Florida). Additionally, type material was examined from NHMUK (Natural History Museum, London, U.K.) and the NHMW (Naturhistorisches Museum Wien, Vienna, Austria).

Specimens studied were entered into the University of Florida Forest Entomology collection database and given a voucher number, which may represent a single pinned specimen, or one or several individuals of the same species housed in a single vial. The determination of species is based only on type material examined. Species are determined by a uniform morphology, and vouchers can be used for future molecular identification. Additional specimens were examined at BPBM.

Photographs of cryo-preserved, non-type specimens were taken with a digital SLR (Canon M50) mounted on an Olympus UIS2 system (BX53 microscope) with $5 \times-40 \times$ objectives, illuminated by diffused halogen lights. Photographs were focus-stacked with Helicon Focus (Helicon Soft) using the pyramid stacking algorithm (method: C), and edited in Photoshop (version CC2020, adobe.com). Type material and other point-mounted material was photographed using various similar methods.

In this paper, species are listed alphabetically. Specimens listed were examined by the authors for this particular study. Additional specimens studied of the included species are listed in Rabaglia et al. (2020), and Johnson et al. (2020b). Diagnosis lists characters relevant for distinguishing the five species present in Hawai' $i$ and may not reliably distinguish these species from other Cryphalus spp. elsewhere. Host plants are listed from specimens encountered in this study, plus additional records from the literature which appear unambiguous. Host plant taxonomy was searched using the plant name resolution service (tnrs.biendata.org, Boyle et al. 2013), and accepted names were selected from the Tropicos database (Tropicos.org, accessed March 2021). Historic host records may refer to collection by vegetation-beating and should be considered with caution.

\section{Systematics}

\section{Cryphalini Lindemann, 1876}

This tribe of bark beetles contains only one genus, Cryphalus. Two other genera present in Hawai' $i$ and traditionally included in this tribe, Hypothenemus Westwood, 1834 (Trypophloeini) and Eidophelus Eichhoff, 1876 (Ernoporini) are not dealt with here.

\section{Cryphalus Erichson, 1836}

\section{Cryphalus brasiliensis Schedl, 1976}

(Figs. 1A-C, 2A-E)

Cryphalus brasiliensis Schedl, 1976: 65.

Type material examined. Holotype Cryphalus brasiliensis Schedl, 1976: BRAZIL • $q$; "Guanabara" [Rio de Janeiro], Botafogo; Jan. 1970; M. Alvarenga leg.; labeled "BOTAFOGO // Guanabara Brasil // 1.1970 // M. Alvarenga leg./// Type Cryphalus brasiliensis// K. -E. Sched1//// Dauernpräparat//Nr. 3541// Fühler // coll. Schedl”; (NHMW).

Other material examined. UNITED STATES • 1 q; Hawai` $\mathrm{i}$, O`ahu, UH Mānoa campus; $21.2954^{\circ} \mathrm{N}$,157.8145 ${ }^{\circ}$ E; 27 Jul. 2018; David Honsberger leg.; ex. Ficus microcarpa; collected from branches, under bark; UFFE:35211 • 1 ऊ’; Same collection data; UFFE:35212 • 110; Same collection data; UFFE:35210 • 31; Hawai' $i$, O'ahu, UH Mānoa campus; $21.2954^{\circ} \mathrm{N},-157.8145^{\circ} \mathrm{E}$; 08 Sep. 2018; David Honsberger leg.; ex. Ficus microcarpa; UFFE:35213 • $1 \mathrm{O}^{\dagger}$; Hawai ${ }^{\circ} \mathrm{i}, \mathrm{O}^{`}$ ahu, UH Mānoa campus; $21.2954^{\circ} \mathrm{N},-157.8145^{\circ} \mathrm{E}$; 11 Jan. 2019; David Honsberger leg.; ex. Ficus microcarpa; 1 male for potential dissection; UFFE:35216 • 80; Hawai'‘i, O'ahu, UH Mānoa campus; 21.2954 ${ }^{\circ}$,-157.8145 ${ }^{\circ}$; 11 Jan. 2019; David Honsberger leg.; ex. Ficus microcarpa; collected from branches, under bark; UFFE:35215 • 70; Hawai 'i, O’ahu, UH Mānoa campus; $21.2954^{\circ} \mathrm{N},-157.8145^{\circ} \mathrm{E}$; 17 May 2019; David Honsberger leg.; ex. Ficus microcarpa; UFFE:35214 • 50; Hawai ‘i, O`ahu, UH Mānoa; $21.2954^{\circ} \mathrm{N},-157.8145^{\circ} \mathrm{E} ; 18$ 
Nov. 2020; David Honsberger leg.; ex. Ficus microcarpa; Ficus microcarpa branches; UFFE:36093 • 10; Hawai' 'i, O‘ahu, UH Mānoa; $21.2952^{\circ} \mathrm{N},-157.8141^{\circ} \mathrm{E}$; 03 Dec. 2020; David Honsberger leg.; ex. Trema orientalis; collected

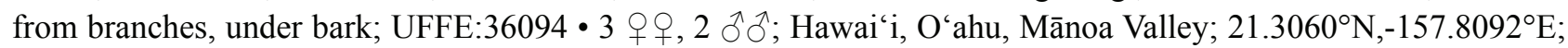
15 Dec. 2020; David Honsberger leg.; ex. Artocarpus altilis; mostly teneral, some mature; UFFE:36083 • 1 ठో; Hawai'i, O`ahu, Mānoa Valley; $21.3060^{\circ} \mathrm{N},-157.8092^{\circ} \mathrm{E}$; 15 Dec. 2020; David Honsberger leg.; ex. Artocarpus altilis; collected from branches, under bark; UFFE:36078 • 1 + ; Same collection data; UFFE:36081 • 1 q; Hawai' ${ }^{\prime}$, O‘ahu, Waimānalo Research Station; $21.3379^{\circ} \mathrm{N},-157.716^{\circ} \mathrm{E}$; 15 Dec. 2020; David Honsberger leg.; ex. Artocarpus altilis; UFFE:36070.
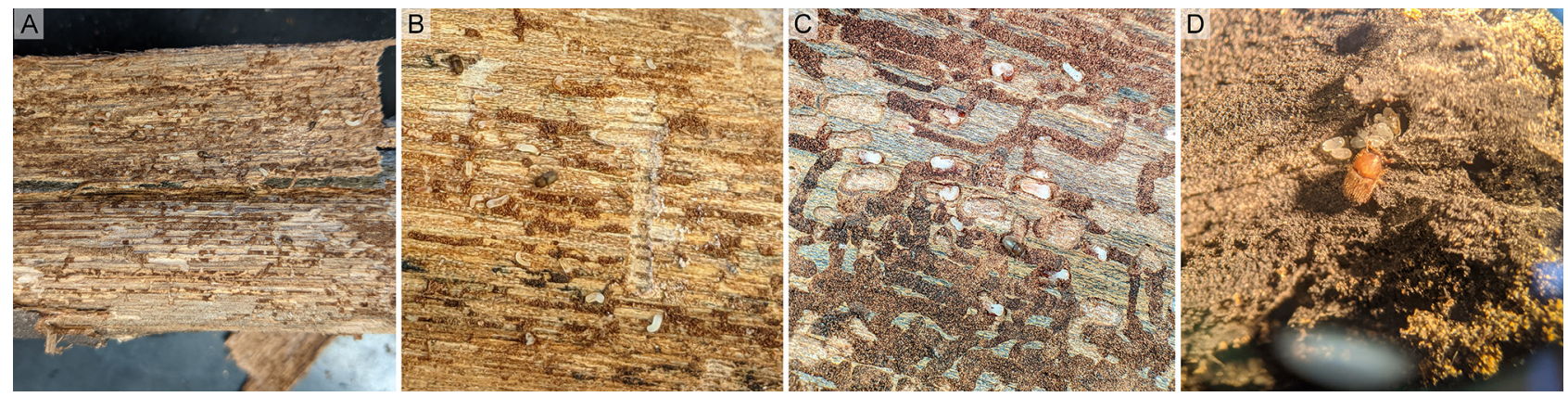

FIGURE 1. Photographs of Cryphalus spp. galleries. A-C: Cryphalus brasiliensis galleries under the bark of Ficus microcarpa with larvae, pupae and mature adults; D: Cryphalus negrosensis adult male and cluster of eggs in Artocarpus altilis fruits. All photos by $\mathrm{DH}$.

Diagnosis: Female. Length 1.2-1.5 mm. Proportions 2.1 times as long as wide. Most mature specimens yellow/ orange-brown. Frons flat or slightly convex (Fig. 2D). Antennae with four funicular segments, club with straight or weakly procurved sutures. Pronotal margin with approx. four asperities of a similar size. Pronotal disc approx. one half of pronotal length, covered with tridentate scale-like setae. Elytral disc more than one half of elytral length. Interstrial bristles flattened with rounded tips, approximately even in length. Striae barely discernable. Ground vestiture clearly scale-like. Setae on lateral area of first visible abdominal ventrite mostly bifid, setae on posterior margin of each abdominal ventrites in distinct row, dagger-like, widest in middle of each seta.

Diagnosis: Male. Similar to female except: upper frons with transverse ridge (Fig. 2E). Protibiae and protarsi with large spatula-shaped setae (Fig. 2B, ventral).

Among the species known from the Hawaiian Islands, this is most similar to Cryphalus sylvicola which can be most reliably distinguished by differences in the interstrial bristles on the elytral disc near the median suture $(C$. brasiliensis: of a similar length to the rest of the interstrial bristles; $v s$. sylvicola: much longer than the rest of the interstrial bristles), and for the males, by the epistomal margin (C. brasiliensis: very weakly chevron-shaped margin; vs C. sylvicola: deep fovea at epistomal margin, with enlarged mandibles), the pronotal slope (C. brasiliensis: many marginal asperities, clearly visible; vs C. sylvicola: barely visible asperities, mostly just rugose cuticle), and by the setae on the protibiae and protarsi (C. brasiliensis: spatula-shaped setae along distal inside margin; vs C. sylvicola: slightly curved, hair-like setae only).

The species is similar to the recently described Cryphalus itinerans Johnson, 2020, a species from Asia which was introduced to Florida. However, the species differ by the interstrial bristles $(C$. brasiliensis: flattened, less than five times as long as wide; vs C. itinerans: narrow, slightly flattened, more than five times as long as wide), and by the setae on the male protibiae and protarsi ( $C$. brasiliensis: spatula-shaped setae along distal inside margin; $v_{s} C$. itinerans: scythe-shaped setae).

This species is also similar to the widely distributed species Cryphalus dilutus Eichhoff, 1878, a probable pest of mango and fig. It is especially similar in the proportions and the large setae on the protibia of males. The species can be distinguished by antennal club sutures (C. brasiliensis: evenly spaced and weakly procurved; $C$. dilutus: unevenly spaced, the most distal more procurved), and by the mesofemoral spur on the males (C. brasiliensis: absent; C. dilutus: present).

Host plants. Moraceae: Artocarpus altilis (Parkinson ex F.A.Zorn) Fosberg, Ficus microcarpa L.; Cannabaceae: Trema orientalis (L.) Blume.

Distribution. Hawai ${ }^{`} i$ : O`ahu; Other locations: Brazil. 

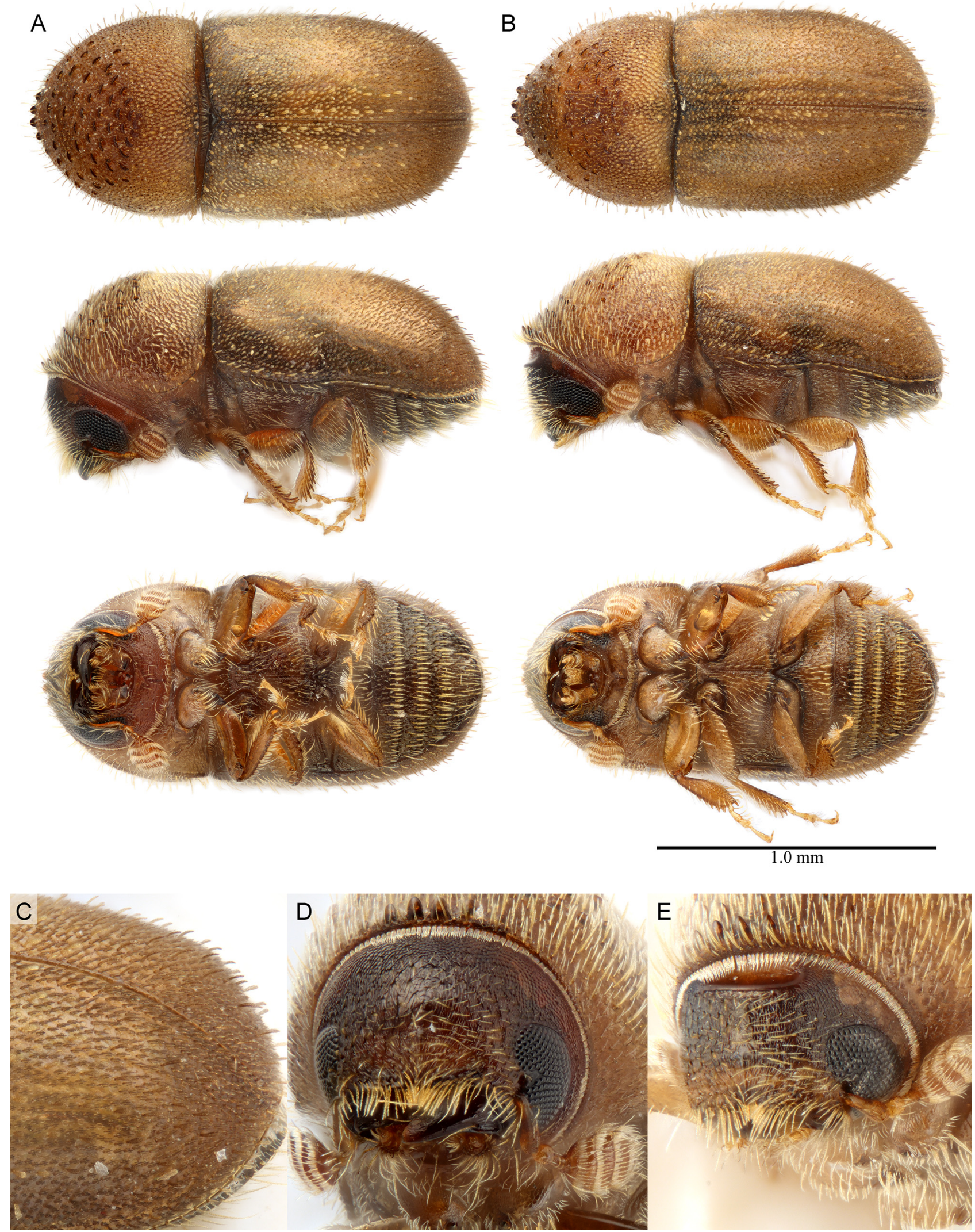

FIGURE 2. Cryphalus brasiliensis Schedl, 1976. A: dorsal, lateral, and ventral photograph of female (UFFE:35211); B: dorsal, lateral, and ventral photograph of male (UFFE:35212); C: declivity of female (UFFE:35211); D: frons of female (UFFE:35211); E: frons of male (UFFE:35212). 
Discussion. Cryphalus brasiliensis is an enigma: described from a single specimen from a region with no known native species. No other specimen has been collected or seen since the description and the specimens reported here, though it is possible that the species may have already been described elsewhere. It is likely that this is an introduced species in Hawai' $i$ but may have been overlooked because of the similarity with C. sylvicola. Specimens were found in this study occurring in especially high densities, feeding and reproducing in the phloem/cambium layer under the bark of $F$. microcarpa branches, possibly expanding necrotic areas.

\section{Cryphalus mangiferae Stebbing, 1914}

(Figs. 3A-E)

Cryphalus inops Eichhoff, 1872: 131 (syn.: Wood 1982: 871, suppressed by Tubbs 1986).

Hypothenemus griseus Blackburn, 1885: 194 (syn.: Wood 1982: 871, suppressed by Tubbs 1986).

"Hypothenemus sp. ?" Stebbing 1903: 68.

Cryphalus (Hypothenemus) mangiferae Stebbing, 1914: 542.

Dacryphalus (Cryphalus) mangiferae (Stebbing, 1914): Hopkins 1927: 28.

Hypocryphalus mangiferae Eggers, 1928: 85 (syn.: Eggers 1931: 185).

Hypocryphalus mangiferae (Stebbing, 1914): Eggers 1931: 185.

Cryphalus subcylindricus Schedl, 1942: 16 (syn.: Schedl 1958: 153).

Cryphalus mimicus Schedl, 1942: 17 (syn.: Kalshoven 1958: 164).

Hypocryphalus opacus Schedl, 1942: 20 (syn.: Kalshoven 1958: 164).

Taenioglyptes artestriatus Browne, 1970: 553 (syn.: Johnson et al. 2020b: 46).

Type material examined. Holotype Hypothenemus griseus Blackburn, 1885. UNITED STATES • 1 ? Holotype; Hawai'i; T. Blackburn leg.; labeled "Type ///// Hawaiian Is.// Rev. T. Blackburn.// 1888-30. //// Cryphalus not Hypothenemus D. J. Atkinson det. 1950//// NHMUK 010805930”; UFFE:26252; (NHMUK). Lectotype Cryphalus mangiferae Stebbing, 1914. INDIA 1 \& Lectotype; 1902; E. P. Stebbing leg.; ex. Mangifera indica; mango twigs; labeled "India// E.P.Stebbing//902-309. //// mango twigs // Cryphalus mangiferae Stb. // C. Beeson det. /// LECTOTYPE Cryphalus mangiferae // S.L.W. 1976 Stebb. ///NHMUK 010805929"; UFFE:26286; (NHMUK) • Paralectotype ${ }^{\top}$ ?; same collection data; UFFE:10426; (NHMUK).

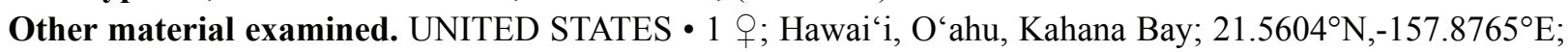
31 Jan. 2020; David Honsberger leg.; ex. Mangifera indica; from branches under bark; UFFE:35199 • 1 ; ; Same collection data; UFFE:35200 • 65; Same collection data; UFFE:35198 • 20; Hawai'i, O'ahu, Waimānalo Research Station; 23 Nov. 2020; David Honsberger leg.; ex. Mangifera indica; from branches under bark; UFFE:36092 • 1; labeled "Honolulu T.H. 9-19-31. H.L. Lyon. ex. mango scions"; (BPBM) • 1; labeled "Honolulu T.H. 10-10-31. H.L. Lyon. Vineyard St. Nursery. ex. mango graft."; (BPBM) • 4 labeled "Moanalua Gardens, Oahu. March '47. Col K.L.Maehler." [det. S.L. Wood]; (BPBM) • 6 labeled "Kawiwi, O'ahu. 8-54. E.J Ford Collector. Mangifera indica."; $(\mathrm{BPBM}) \cdot 2$ labeled "Wahiawa Wahiawa, O'ahu. 9-58. E.J. Ford Jr. Collector"; (BPBM) • 1; labeled "Hawaii No. 2443. Mangifera indica."; (BPBM) • 1; labeled "Damon Tract, Oahu. 2-53. Coll. Ford."; (BPBM) • 1 labeled "Kalihi Val. Oahu. E. J. Ford Jr. Collector.”; (BPBM).

Diagnosis: Female. Length 1.6-2.2 mm. Proportions 2.2-2.3 times as long as wide. Matures yellow-orangebrown, rarely dark brown. Frons with fine aciculations converging at center of epistoma (Fig. 3D). Antennal funiculus with five funicular segments, club with procurved sutures. Pronotal margin with four asperities, the median pair larger. Pronotal disc approx. 1/3 of pronotal length, with only hair or dagger-like setae. Elytral disc more than half of elytral length. Interstrial bristles hair-like, all of similar length. Striae clearly visible as rows of punctures without ground vestiture. Ground vestiture dagger-like. Setae on lateral area of first visible abdominal ventrite mostly bifid, setae on posterior margin of abdominal ventrites hair-like and not in a distinct row.

Diagnosis: Male. Similar to female except: protibiae and protarsi with coarse, curved setae (Fig. 3B, ventral).

The long pronotal disc with no scale-like setae makes this easy to distinguish from all other Hawaiian Cryphalus.

Host plants. Anacardiaceae: Mangifera indica L., M. odorata Griff. (Kalshoven 1958), Choerospondias axillaris (Roxb.) B. L. Burtt \& A. W. Hill; Euphorbiaceae: Codiaeum variegatum (L.) A. Juss. [not a confirmed reproductive host].

Distribution. Hawai'i: O`ahu. Other locations: Pan-tropical. 

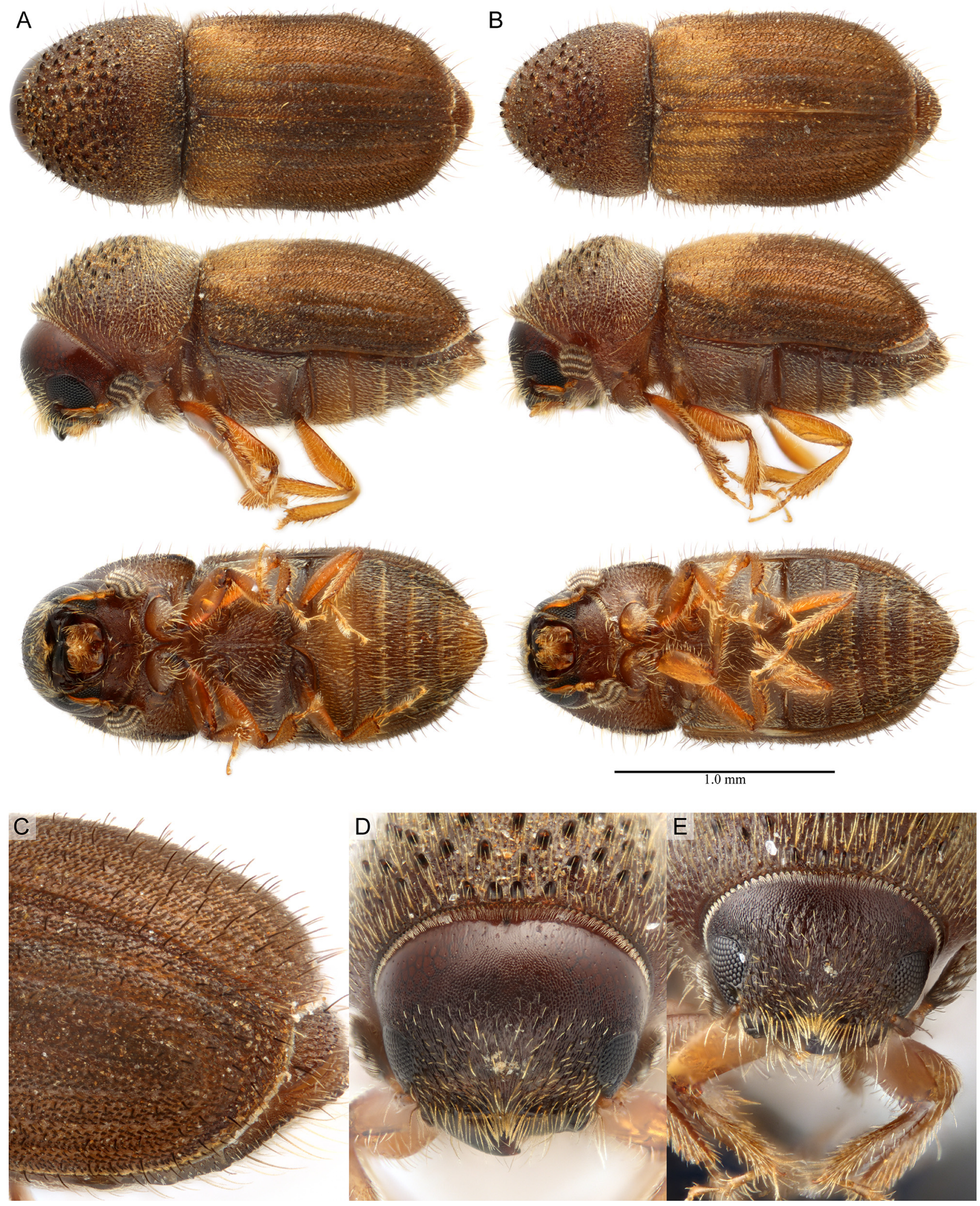

FIGURE 3. Cryphalus mangiferae Stebbing, 1914. A: dorsal, lateral, and ventral photograph of female (UFFE:35199); B: dorsal, lateral, and ventral photograph of male (UFFE:35200); C: declivity of female (UFFE:35199); D: frons of female (UFFE:35199); E: frons of male (UFFE:35200). 
Discussion. Cryphalus mangiferae is a pan-tropical species present wherever mango is grown. Two other Cryphalus species are known from mango, C. dilutus Eichhoff, 1878 and C. paramangiferae Johnson, 2020. We only examined specimens from $\mathrm{O}^{\prime}$ ahu, though it is likely to be present on other islands.

\section{Cryphalus negrosensis Browne, 1979}

(Figs. 1D, 4A-D)

Cryphalus negrosensis Browne, 1979: 85.

Type material examined. Holotype Cryphalus negrosensis Browne, 1979. PHILIPPINES • 1 q Holotype; Negros, Bais, Dewey Island; 11 Aug. 1976; G. B. Vida leg.; "On seeds of small sp. of bacauan"; NHMUK: 010805985; UFFE:26214; (NHMUK) • 1 § Paratype; same collection data; UFFE:10411; (NHMUK); [2 additional paratypes in NHMUK present, 2 paratypes missing from point].

Other material examined. UNITED STATES • 7 우, $2 \hat{\delta} \delta$; Hawai ‘i, Hawai' $i$ County, Kainaliu Experiment Station; 04 Oct. 2010; D. Oishi leg.; UFFE:15076-15079,15083,15084,15086 (UFFE) •1 §o; Hawai‘i, Hawai‘i County, Kainaliu Experiment Station; 02 Nov. 2010; J. M. Scharff leg.; UFFE:15074; (UFFE) • 1 \%; Same collection data; UFFE:15075; (UFFE) • 1 क; Same collection data; UFFE:15080 • 1 ō; Same collection data; UFFE:15081 • 1 q; Same collection data; UFFE:15082 • 1 क; Same collection data; UFFE:15085 • 1 \%; Same collection data; UFFE:15087 • 1 q; Same collection data; UFFE:15088; (UFFE) • 1 ô; Hawai`i, O‘ahu, UH Mānoa campus; $21.3017^{\circ} \mathrm{N},-157.8150^{\circ} \mathrm{E}$; Jan. 2019; David Honsberger leg.; ex. Artocarpus altilis; ex. breadfruit fruits; UFFE:35204 • 1 q; Same collection data; UFFE:35202 • 1 ô; Same collection data; UFFE:35203 • 65; Same collection data; UFFE:35201 • 1; Hawai'i, Moloa'a, Moloa'a Coffee; 01 Aug. 2016; Jared Bernard leg.; UFFE:26364• 1 ơ; Hawai'i, Moloa'a, Moloa'a Coffee; 08 Jul. 2017; Jared Bernard leg.; UFFE:26366 • 12; Hawai‘i, Kaua'i, Numila, Kauai Coffee; 18 Jan. 2017; Curtis Ewing leg.;”04Q 0447858 2421109”; UFFE:26363. • 38; Hawai'i, O'ahu, UH Mānoa; $21.3017^{\circ} \mathrm{N},-157.8150^{\circ} \mathrm{E}$; Oct. 2020; David Honsberger leg.; ex. Artocarpus altilis; Artocarpus altilis fruits; all mature, heads retracted; UFFE:36085 • 100; Hawai`i, O`ahu, UH Mānoa; $21.2993^{\circ} \mathrm{N},-157.8189^{\circ} \mathrm{E} ; 26$ Oct. $^{\circ}$ 2020; David Honsberger leg.; ex. Artocarpus altilis; Artocarpus altilis fruits; mostly mature, some teneral, some dead; UFFE:36089 • 1 q; Hawai' ${ }^{`}$, O`ahu, UH Mānoa; $21.2993^{\circ} \mathrm{N},-157.8189^{\circ} \mathrm{E}$; 26 Oct. 2020; David Honsberger leg.; ex. Artocarpus altilis; Artocarpus altilis fruits; UFFE:36087 • 1 ö; Same collection data; UFFE:36088 • 150; Hawai' i, O`ahu, UH Mānoa; $21.2993^{\circ} \mathrm{N},-157.8189^{\circ} \mathrm{E} ; 26$ Oct. 2020; David Honsberger leg.; ex. Artocarpus altilis; fruits; UFFE:36086 • 50; Hawai'i, O`ahu, Waimānalo Research Station; $21.3379^{\circ} \mathrm{N},-157.7160^{\circ} \mathrm{E}$; 15 Dec. 2020; David Honsberger leg.; ex. Artocarpus altilis; fruits; UFFE:36090 - 2 Hawai'i, O’ahu, UH Mānoa; 21.2994N, $-157.8179^{\circ} \mathrm{E}$; 21 Jan. 2021; David Honsberger leg.; ex. Adansonia digitata adults with eggs, in the husk and fruit (D.Honsberger collection, not yet deposited); • 4 Hawai ${ }^{\prime}$, Kainaliu Expt. Station. 4-11.x.2010 ex. Ethanol methanol lindgren trap. Coll. D. Oishi. Ericryphalus longipilus Schedl, 1943? det. G.A. Samuelson 2010; (BPBM).

Diagnosis: Female. Length 1.3-1.6 mm. Proportions 2.0 times as long as wide. Matures red-brown. Frons with small median keel on lower half (Fig. 4C). Antennal funiculus with four funicular segments, club with straight sutures. Pronotal margin with 2-4 small asperities, the median pair larger. Pronotal disc approx. 1/5 of pronotal length, with hair-like setae only. Elytral disc about half of elytral length. Interstrial bristles hair-like, all of similar length. Striae weakly visible. Ground vestiture mostly hair-like, with widened bases and tapered tips. Setae on lateral area of first visible ventrite a mix of hair-like and bifid, setae on posterior margin of abdominal ventrites hair-like and not in a distinct row.

Diagnosis: Male. Similar to female except: upper frons with fine, raised, transverse carina (Fig. 4D), often obscured by pronotum. Pronotum with asperities on margin fused to a sclerotized ridge (Figs. 4B, 4D).

Host plants. Moraceae: Artocarpus altilis, Ficus L. sp.; Anacardiaceae: Mangifera indica; Fabaceae: Inga edulis Mart.; Malvaceae: Adansonia digitata L.; Rhizophoraceae: "bacauan" [likely Rhizophora L. or Brugueira Lam.].

Distribution. Hawai'i: Hawai'i; Kaua'i; O'ahu. Other locations: Philippines; Papua New Guinea.

Discussion. This species is often collected in fruits, an unusual environment for Cryphalus. In Hawai' $i$, they have been collected from Artocarpus altilis (breadfruit) fruits, as well as Inga edulis fruits (ice cream bean) and Adansonia digitata (baobab). Additionally, specimens have been collected from Mangifera and Ficus fruits in Papua New Guinea (Johnson, pers. obs.). The type series was collected from mangrove "seeds", probably referring to the propagules. It is unclear if they reproduce in all of these fruits; reproduction has only been observed in Artocarpus fruits. 
A
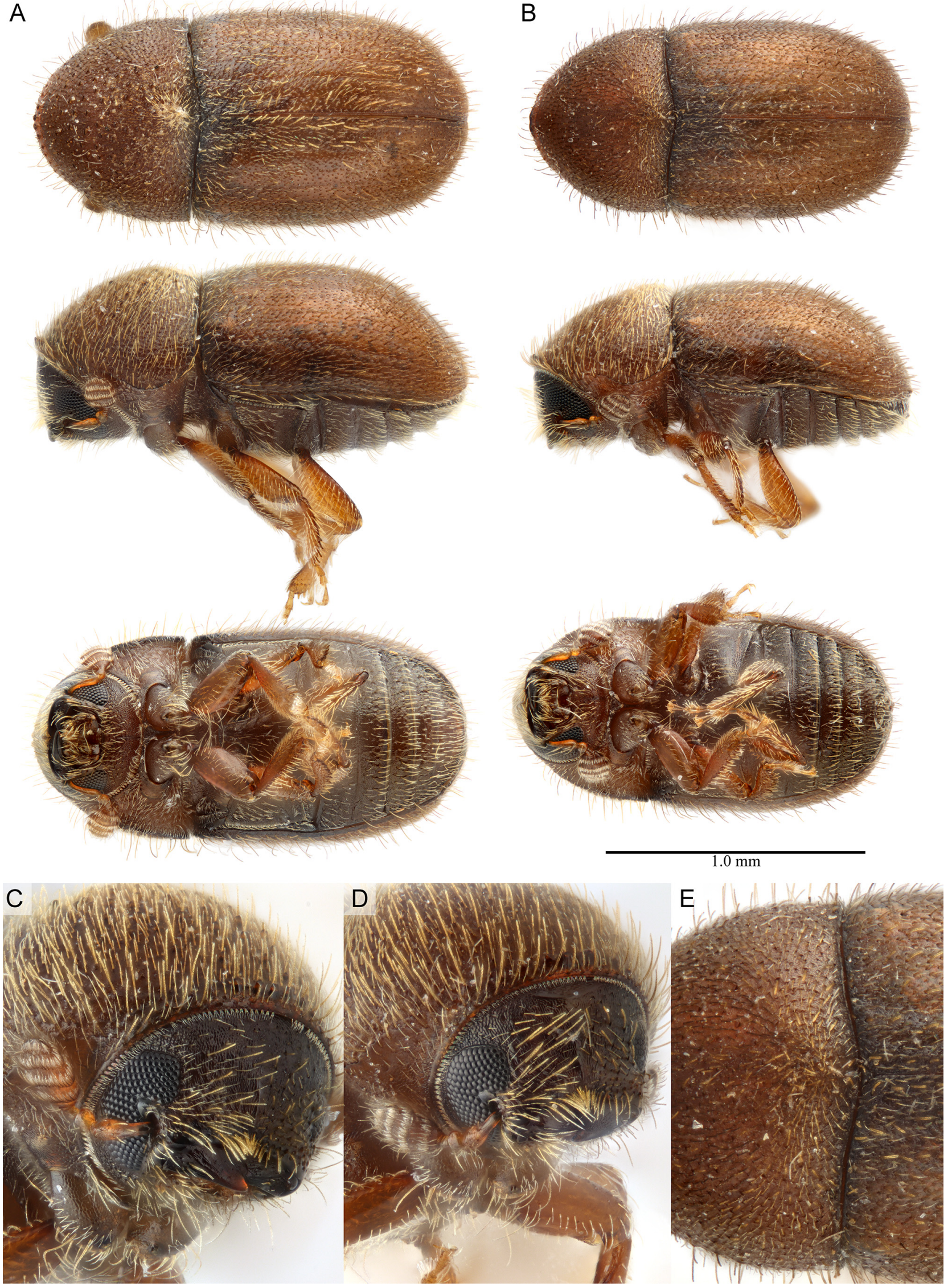

FIGURE 4. Cryphalus negrosensis Browne, 1979. A: dorsal, lateral, and ventral photograph of female (UFFE:35202); B: dorsal, lateral, and ventral photograph of male (UFFE:35203); C: frons of female (UFFE:35202); D: frons of male (UFFE:35203); E: dorsal view of base of pronotum and elytra of male (UFFE:35203). 
On breadfruit, these were observed boring into unripe fruits. While this species has not been reported as a pest in these systems, this behavior may cause premature ripening or decay of fruits, and make further introductions elsewhere plausible. This behavior has not been observed on other specialty crops involved in international trade such as mango and figs, but the records of it also attacking mangroves, likely the living propagules, could suggest that it may attack living tissue of other plant hosts.

The species was recorded from Hawai'i by Bernard et al. (2018) under the name Cryphalus longipilus. The material was determined as Cryphalus longipilus Schedl, 1943 by AJJ, based on non-type specimens collected in Hawai' $\mathrm{i}$ in 2010 (UFFE:15074-15088) labeled as "?Ericryphalus longipilus Schedl" by G. A. Samuelson in 2010. AJJ's determination was accompanied by a caveat that the species might be synonymous with $C$. negrosensis (Bernard et al. 2018). The material examined in this study included loans of unpublished vouchers from Bernard et al. (2018) (UFFE:26363,26364,26366).

The authors have not yet been able to examine type material of $C$. longipilus, but we now consider it unlikely that it is synonymous with C. negrosensis. Wood (1960) redescribed C. longipilus (Schedl, 1943), and noted a conspicuous tuft of denser, more red colored setae present at the base of the declivity of interstriae 1 in the female. Although Wood's redescription is detailed, it does not mention the conspicuous keel on the lower half of the frons of all specimens, and the males with the particularly unusual character of fused serrations on the anterior margin of the pronotum. Based on that description alone, the specimens from Hawai'i do not match, and there are no bona fide records or specimens of $C$. longipilus from Hawai' $i$.

Additionally, the lectotype of Cryphalus walkeri (Blandford, 1896) and the holotype of its junior synonym, Coccotrypes hagedorni Eggers, 1908 appear to have a superficial resemblance to this species. The lectotype of $C$. walkeri is a male (by the shallow-sloped and flat pronotal declivity with minute asperities), but it clearly has marginal asperities not fused into a continuous ridge, whereas the type of Co. hagedorni is a female and may not be diagnosable with the known characters. Further investigation with more specimens from the type localities, with molecular data or at least more characters (e.g., frons, proventriculus, and aedeagus) would be needed before making further taxonomic judgements.

\section{Cryphalus sylvicola (Perkins, 1900)}

(Figs. 5A-D)

Hypothenemus sylvicola Perkins, 1900: 181.

Cryphalus sylvicola (Perkins, 1900): Hagedorn 1910: 88.

Ericryphalus henshawi Hopkins, 1915: 38 (syn.: Wood 1960: 23).

Ptilopodius sylvicola (Perkins, 1900): Schedl 1939: 327.

Ericryphalus sylvicola (Perkins, 1900): Schedl 1941: 111.

Cryphalus sylvicola obliquus Schedl, 1950: 48. (syn.: Wood 1960: 23).

Cryphalus dimorphus Schedl, 1950: 49 (syn.: Beaver 1991: 89).

Ericryphalus sylvicolus (Perkins, 1900): Swezey 1954: 116, 162, incorrect spelling.

Taenioglyptes sylvicola (Perkins, 1900): Browne 1970: 540.

Type material examined. Holotype Hypothenemus sylvicola Perkins, 1900: UNITED STATES • 1 ๙ Holotype; Hawai'i, Lāna‘i Island, Lâna'i; Jan. 1894; labeled "Hawaiian Is.//1900-99////Hypothenemus sylvicola // Type // Lanai 2500ft// I.1894.//// Cryphalus not Hypothen. D. J. Atkinson det 1950// NHMUK 010805975"; UFFE:26227; (NHMUK). Holotype Ericryphalus henshawi Hopkins, 1915: q United States, Hawai' ${ }^{1}$. Hilo; H. W. Henshaw leg.; USNMENT:01356810.

Other material examined. UNITED STATES • 1 $\$$; Hawai'i, Hawai`i Isl., 7 mi. S. Hilo Hwy. 11; 20 Nov. 1976; C. W. and L. B. O’Brien leg.; UFFE:12486; (FSCA) • 1; Hawai ‘i, Kaua ‘i, Moloa'a, Moloa‘a Coffee; 29 Nov. 2016; UFFE:26365 • 1 O’; Hawai`i, O‘ahu, Tantalus; O. H. S. leg.; ex. Clermontia; labeled "Tantalus Oahu, Coll. O.H.S"; collector full name, date, method unknown; host assumed from similarly labeled specimen; UFFE:15100; (UFFE) • 1 ○; Same collection data; UFFE:15101; (UFFE) • 1 ; Hawai 'i, O`ahu, Tantalus; O. H. S. leg.; ex. Clermontia; labeled "Tantalus Oahu, Coll. O.H.S"; "9 ex bark Clermontia"; UFFE:15102; (UFFE) • 1 §’; Hawai'i, O‘ahu, Mānoa; 04 Jan. 1920; J. C. Bridwell leg.; ex. Clermontia; UFFE:15099; (UFFE) • 1 P; Hawai'i, O‘ahu, Kailua; 03 Aug. 1964; C. J. Davis leg.; ex. Morus; ex. mulberry (weak branches); labeled: "Kailua, Hawaii, VIII3-1964//// ex mulberry (weak branches)////C.J. Davis H-64-41, Collector//// 1 //// State Ento. Branch Hawaii No. 
64-979//// Ericryphalus sylvicola (Perk).Wood det (“64)”; UFFE:15103; (UFFE) • 1 क ; Hawai ‘i, O‘ahu, Kailua; 03 Aug. 1964; C. J. Davis leg.; ex. Morus; ex. mulberry (weak branches); labeled: "Kailua, Hawaii, VIII-3-1964//II ex mulberry (weak branches)////C.J. Davis H-64-41, Collector//// 6 [or 9?]”; UFFE:15104; (UFFE) • 1 q; Hawai ‘i, O`ahu, Kailua; 03 Aug. 1964; C. J. Davis leg.; ex. Morus; ex. mulberry (weak branches); labeled: "Kailua, Hawaii, VIII-3-1964//// ex mulberry (weak branches)///C.J. Davis H-64-41, Collector"; UFFE:15105; (UFFE) • 1 q;

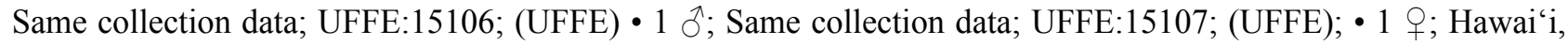

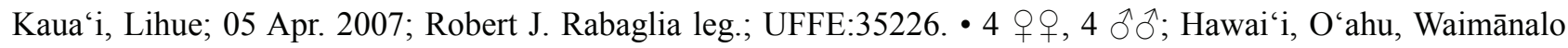
Research Station; $21.3339^{\circ}$ N,-157.7077 E; 19 Nov. 2020; David Honsberger leg.; ex. Morus; Morus sp. branches; UFFE:36065 • 16; Hawai'i, O‘ahu, Mānoa Valley; 21.3060 N,-157.8092E; 15 Dec. 2020; David Honsberger leg.; ex. Artocarpus altilis; collected from branches, under bark; UFFE:36082 • 1 O; Hawai'i, O`ahu, Mānoa Valley; 21.3060 N,-157.8092 ${ }^{\circ}$ E; 15 Dec. 2020; David Honsberger leg.; ex. Artocarpus altilis; collected from branches, under bark; UFFE:36076 • 1 क; Same collection data; UFFE:36077 • 50; Hawai ‘i, O'ahu, Waimānalo Research Station; $21.3339^{\circ} \mathrm{N},-157.7077^{\circ} \mathrm{E} ; 15$ Dec. 2020; David Honsberger leg.; ex. Morus; from branches; UFFE:36064 - 1 क; Same collection data; UFFE:36060 • 1 ơ; Same collection data; UFFE:36061 • 1 क; Same collection data; UFFE:36058 • 1 \%; Same collection data; UFFE:36059. • 1; [Undesignated specimen from type series?] Hawai 'i, Lāna'i Island, "Lanai 2000 ft. I.1894. Lana'i; 2000 ft. Perkins, 12.1893. Fauna Hawaiiensis collection"; [Additional point and label of same collection data without a specimen]; (BPBM)• 1; Hawaiian Ids. O'ahu. S.E. Ko'olau Mts. July 1917. Pauoa J.; Bred ex. dead twigs Clermontia under bark. J.C. Bridwell Collector; (BPBM). 15 ; Similarly mounted specimens labeled as "Pauoa 7-17. J.C.B. O‘ahu." • 1; Hawaiian Ids. O‘ahu. S.E. Ko'olau Mts. July 1917. Pauoa J.; J.C. Bridwell Collector; (BPBM). •1; Mt. Tantalus. 6.10.17. O'ahu. J.C. Bridwell Collector. Ericryphalus sylvicola (Perk.) Det. By O.H. Swezey. [labeled with "? mangiferae"]; (BPBM).

Diagnosis: Female. Length 1.2-1.5 mm. Proportions 2.1-2.3 times as long as wide. Color variable, yellow brown to dark brown. Frons weakly convex (Fig. 5C). Antennal funiculus with four funicular segments, club with straight or recurved sutures. Pronotal margin with four asperities, the median pair much larger and contiguous. Pronotal disc approx. $1 / 3$ of pronotal length, tuberculate surface texture, with mostly scale-like setae. Elytral disc more than half of elytral length. Interstrial bristles erect, long and hair-like on elytral disc, curved scale-like on elytral declivity, pointing towards apex. Striae barely discernable. Ground vestiture scale-like. Setae on lateral area of first visible abdominal ventrite a mix of bifid and hair-like, setae on posterior margin of abdominal ventrites hair-like and not in a distinct row.

Male similar to female except: frons with deeply emarginated epistomal margin (Fig. 5D), and with a transverse ridge in upper level (obscured by pronotum in Fig. 5D). Pronotum with gentle slope, projecting strongly. Elytral disc shorter than female, about half elytral length.

Cryphalus sylvicola is similar to C. brasiliensis, especially the females, which can be distinguished by the interstrial bristles on the elytral disc (C. sylvicola: long, erect, hair-like, much longer than those on the declivity; vs $C$. brasiliensis: short, slightly flattened, of a similar length and shape to rest of elytra). Males can be distinguished more easily, with additional differences in the epistomal margin (C. sylvicola: deeply concave; vs C. brasiliensis: flat, similar to female), the pronotal slope (C. sylvicola: very flat with only small asperities; vs C. brasiliensis: flatter than female, but 30 or more small asperities clearly visible), and by the setae on the protarsi and protibiae (C. sylvicola: coarse, curved hair-like; $v s$. brasiliensis: spatula-shaped, obviously wide and flat near the tips).

Host plants. Aquifoliaceae: Ilex L. sp. (Wood \& Bright 1992); Moraceae: Artocarpus altilis, Morus L. sp., Ficus sp. ("banyan", Schedl 1941); Campanulaceae: Clermontia Gaudich. sp. (Schedl 1941); Fabaceae: Cajanus cajan (L.) Millsp. (Schedl 1941), Bauhinia variegata (L.) Benth. (Beaver 1976), Leucaena leucocephala (Lam.) de Wit (Beaver 1976), Acacia Mill. sp. (Wood \& Bright 1992); Malvaceae: Theobroma cacao L. (Beaver 1976); Passifloraceae: Passiflora L. sp. (Beaver 1976); Urticaceae: Pipturus Wedd. sp. (Swezey 1941).

Distribution. Hawai'i: Hawai'i; Lâna'i; Kaua'i; O’ahu. Other locations: American Samoa; Samoa; Cook Isl.; Federated States of Micronesia (Caroline Isl.); Fiji; French Polynesia (Marquesas Isl.); Guam, Northern Mariana Isl.; Niue; Tonga.

Discussion. The synonymy of $C$. swezeyi and $C$. pini is rejected here, see notes under $C$. pini. The correct citation for the synonymy of Ericryphalus henshawi is ambiguous, since the apparent synonymy by Schedl (1941), cited by Wood \& Bright (1992) and Johnson et al. (2020a), is only a note that they may be the same based on the description. Wood (1960) listed C. henshawi under C. sylvicola without citing any synonymy, and Schedl (1963b) made an express statement of synonymy. 
This species is widespread across the Pacific islands. The distribution and host range indicated is of verified records based on the material examined, and other material confirmed to match the description of $C$. sylvicola and not $C$. swezeyi or C. pini. These taxonomic changes remove Pinus and Piper sp. from the verified host range, and the Philippines from the verified distribution. The broad host range is still remarkable, since most Cryphalus species are restricted to one family of plant hosts.
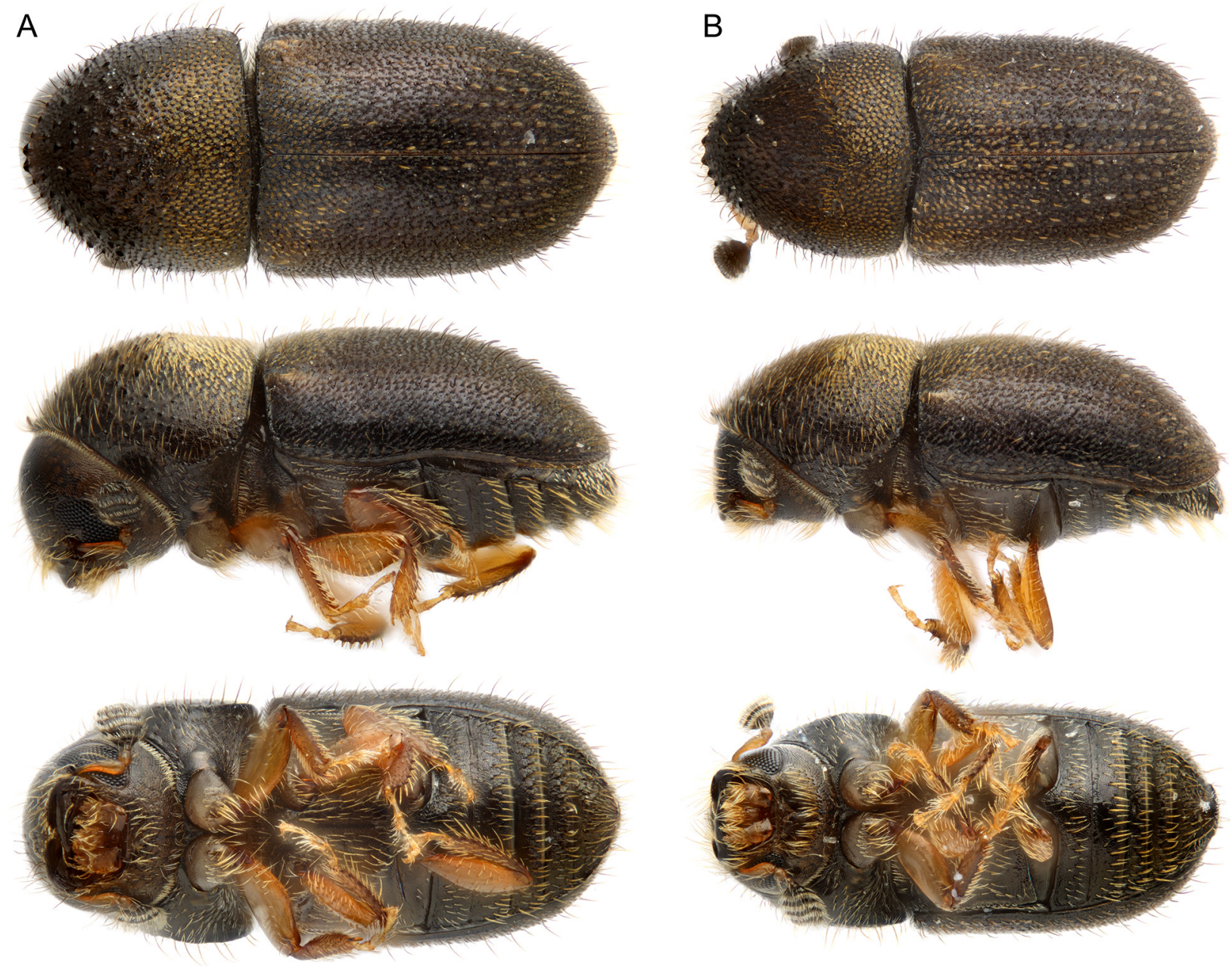

C

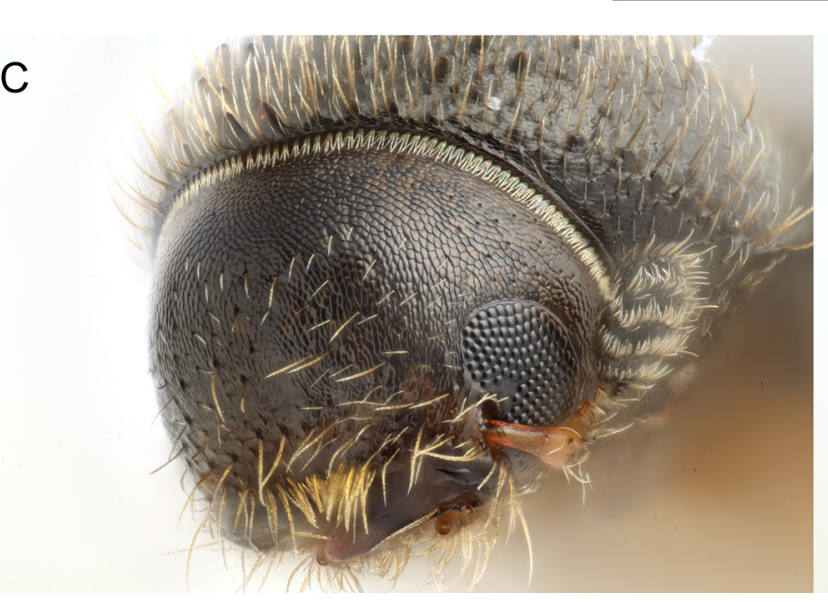

$1.0 \mathrm{~mm}$

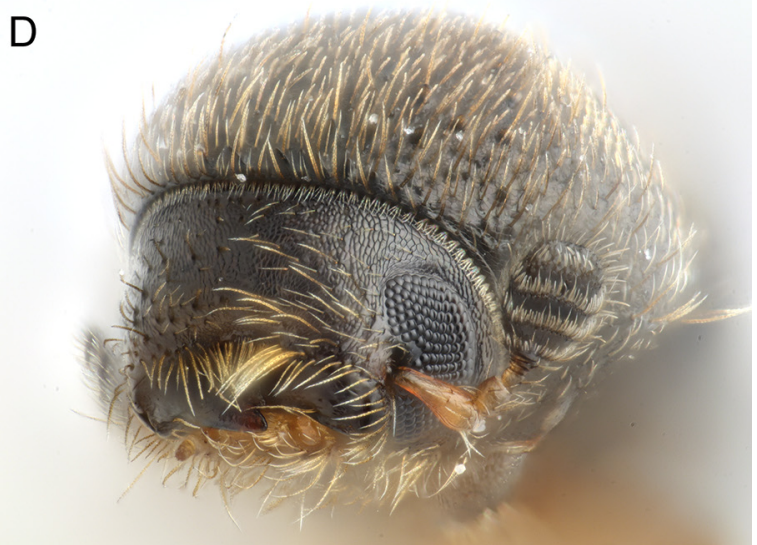

FIGURE 5. Cryphalus sylvicola (Perkins, 1900). A: dorsal, lateral, and ventral photograph of female (UFFE:36060); B: dorsal, lateral, and ventral photograph of male (UFFE:36061); C: frons of female (UFFE:36060); D: frons of male (UFFE:36061). 


\section{Cryphalus trypanoides (Beeson, 1935)}

(Figs. 6A-D)

Ericryphalus trypanoides Beeson, 1935: 106.

Cryphalus trypanoides Beeson, 1935: Wood \& Bright 1992: 897; Johnson et al. 2020a: 24 (erroneously treated as original combination).

Cryphalus mollis Schedl, 1955: 288. syn. nov.

Hypocryphalus mollis (Schedl, 1955): Beaver 1987: 67.

Hypocryphalus tongaensis Schedl, 1979b: 104 (syn.: Beaver 1987: 67).

Type material examined. Holotype Ericryphalus trypanoides Beeson, 1935: FRENCH POLYNESIA 1 \& Holotype; Marquesas Islands, 'Ua Pou, Hakahetau valley; (BPBM).

Other material examined. UNITED STATES 52; Hawai' $\mathrm{i}$, O'ahu, Mānoa Valley; $21.3060^{\circ} \mathrm{N},-157.8092^{\circ} \mathrm{E} ; 15$ Dec. 2020; David Honsberger leg.; ex. Artocarpus altilis; from branches under bark; UFFE:36084 • 1 + ; Hawai' $\mathrm{i}$, O‘ahu, Mānoa Valley; $21.3060^{\circ} \mathrm{N},-157.8092^{\circ} \mathrm{E} ; 15$ Dec. 2020; David Honsberger leg.; ex. Artocarpus altilis; from branches under bark; mostly teneral, some mature; UFFE:36079 • 1 ठ̊ં; Same collection data; UFFE:36080 • 60; Hawai' i, O`ahu, Waimānalo Research Station; $21.3379^{\circ} \mathrm{N},-157.7160^{\circ} \mathrm{E} ; 15$ Dec. 2020; David Honsberger leg.; ex. Artocarpus altilis; from branches under bark; UFFE:36074 • 40; Same collection data; UFFE:36073 - 1 ○े; Same collection data; UFFE:36072 • 1 क; Same collection data; UFFE:36066 • 1 đ̊; Same collection data; UFFE:36067

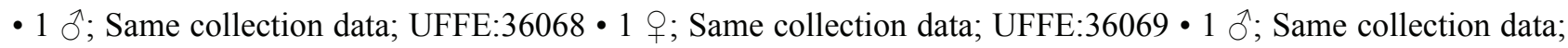
UFFE:36071.

Diagnosis: Female. Length 1.4-1.8 mm. Proportions 2.00-2.05 times as long as wide. Color orange/red-brown. Frons convex, indistinct glossy cuticle in middle of frons (Fig. 6C). Antennal funiculus with five funicular segments, club with straight sutures. Pronotal margin with 6-8 asperities, the median pairs only slightly larger or of a similar size to the others, the outermost pair sometimes smaller. Pronotal disc approx. 1/4 of pronotal length, tuberculate surface texture, with mostly scale-like setae. Elytral disc less than half of elytral length. Interstrial bristles slightly flattened, ribbon-like, erect on disc, curved posteriorly on declivity. Striae barely discernible. Ground vestiture tridentate, scale-like. Setae on first visible abdominal ventrite mostly single (not bifid), setae on posterior margin of abdominal ventrites hair-like and not in a distinct row.

Diagnosis: Male. Similar to female except: length 1.3-1.7 mm. Proportions 1.95-2.00 times as long as wide. Frons with deeply emarginated epistomal margin, and with a transverse ridge in upper level. Pronotum with a flattened slope.

Host plants. Moraceae: Artocarpus altilis.

Distribution. Hawai ${ }^{1} \mathrm{i}$ : O'ahu. Other locations: French Polynesia (Marquesas); Fiji; Tonga; Samoa; American Samoa; Niue (Beaver \& Maddison 1990).

Discussion. Previously, only a single record of this species for Hawai' $i$ existed, presented by van Zwaluwenberg (1956) as "? Ericryphalus trypanoides Beeson", determined by S. L. Wood, with the label data "Manoa, Oahu, Jan 7, 1948-Jan 24, 1950, O. H. Swezey, ex. dead branches and dead bark of breadfruit". The specimens were not located but given that we collected specimens from the same host and a nearby locality, it is presumed that the species has been established in Hawai' $i$ for some time, at least since 1950.

The holotype at BPBM is a female (not a male, as suggested by Wood \& Bright 1992), and is consistent with the specimens here. Male Cryphalus typically possess more diagnostic characters, but neither C. mollis, nor C. trypanoides have any males in the type series. The morphology of the males is typical of specimens determined as $C$. mollis from Fiji and specimens from American Samoa.

This species is widespread across the Pacific islands, now recorded from Fiji, Tonga, Niue, American Samoa, Samoa, and Hawai'i. It seems plausible that this species was introduced with Artocarpus. 
A
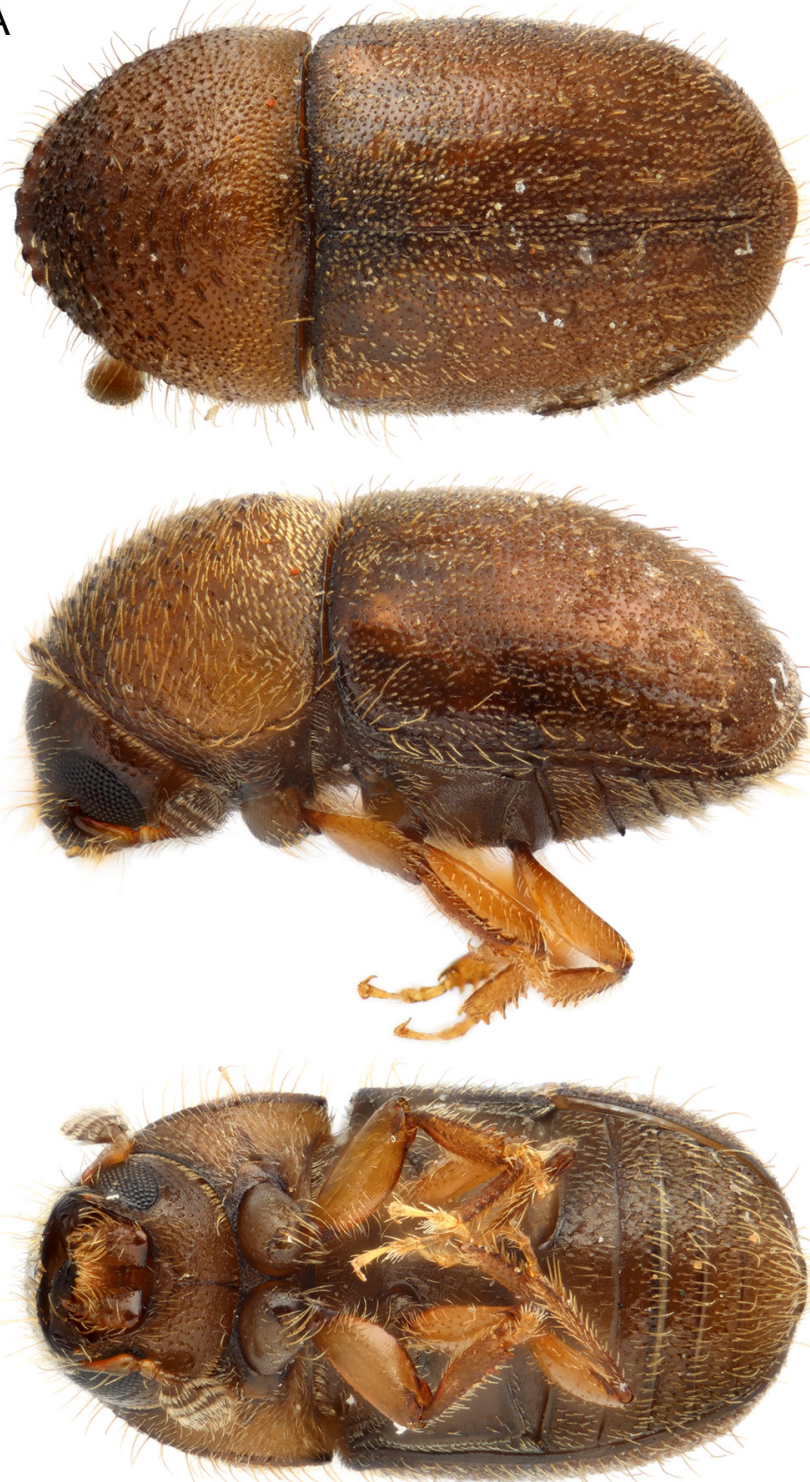

C

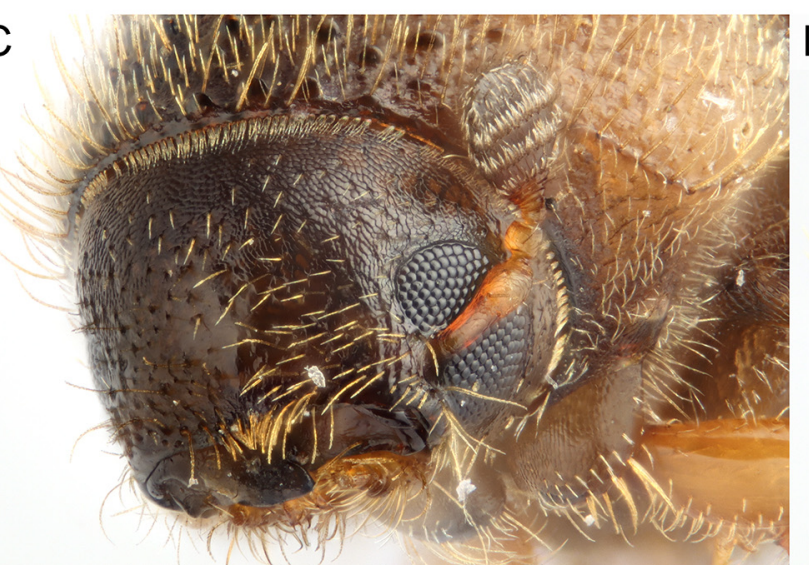

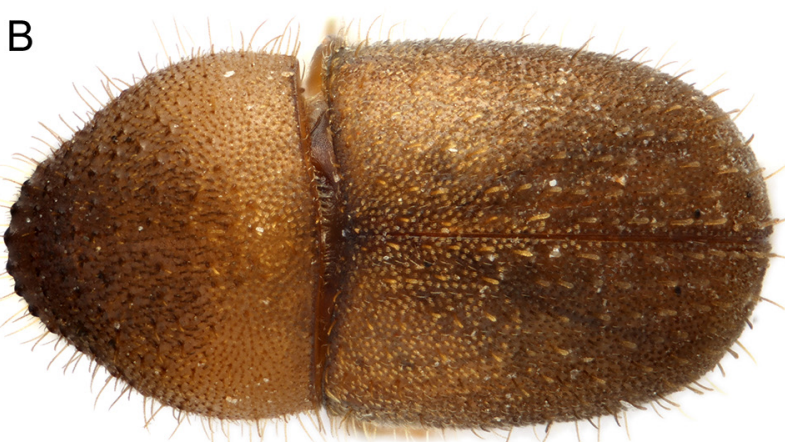
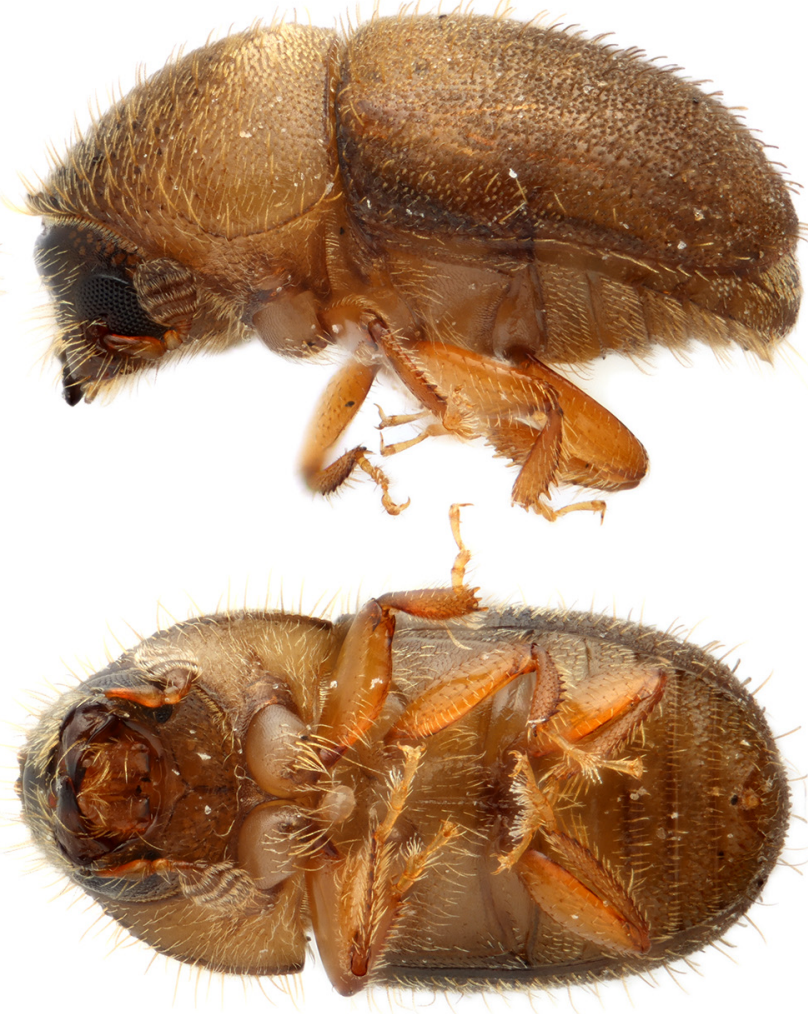

$1.0 \mathrm{~mm}$

D

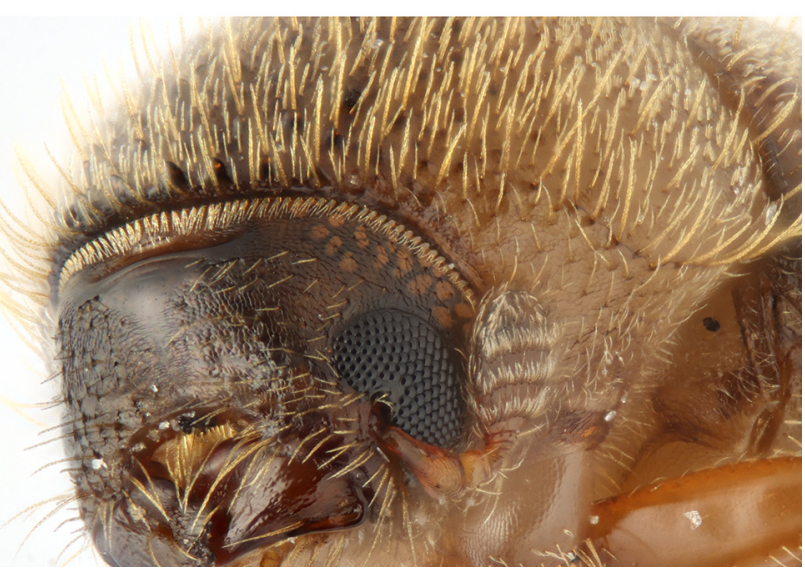

FIGURE 6. Cryphalus trypanoides (Beeson, 1935). A: dorsal, lateral, and ventral photograph of female (UFFE:36066); B: dorsal, lateral, and ventral photograph of male (UFFE:36071); C: frons of female (UFFE:36066); D: frons of male (UFFE:36071). 


\section{Cryphalus pini (Hopkins, 1915) stat. res.}

Piperius pini Hopkins, 1915: 39.

Cryphalus pini (Hopkins, 1915): Schedl 1963b: 62.

Type material examined. Holotype Piperius pini Hopkins, 1915: PHILIPPINES • 1 q : Luzon: Baguio; labeled: "Baguio // Luzon // P.I///Pinus insularis///C. V. Piper coll./// 10.V.11 ////9136a Hopk. US //// USNMENT01356854 //// Type No. 7603 //// Piperius pini Hopk. ////Leg mounted//// Antenna mounted//"; 1911-10-04 [According to Hopkins 1915, does not match label]; (NMNH).

Discussion. Piperus pini Hopkins, 1915 is widely accepted as a junior synonym of C. sylvicola (Wood 1986; Wood \& Bright 1992; Johnson et al. 2020a) citing Schedl (1963b). However, this was an error from poor word choice and incorrect translation. After stating that Ericryphalus henshawi Hopkins, 1915 was identical to Hypothenemus sylvicola Perkins, 1900, Schedl states that Piperius pini is placed in an equal position ['eine gleiche Stellung'], the position referring to the genus rather than the species. Schedl listed P. pini as valid in a later catalogue of the Philippine fauna (Schedl 1966), and the species was not treated in any later publication.

The holotype clearly differs from C. sylvicola by the hair-like setae on the pronotal disc, as well as overall shape and proportions. There are several similar Pinus feeding species in East Asia. No other Cryphalus is known to feed on both conifers and angiosperms, and this taxonomic change rejects Pinus as a known host for C. sylvicola.

\section{Cryphalus swezeyi Schedl, 1942 stat res.}

Cryphalus swezeyi Schedl, 1942: 147.

Type material examined. Lectotype Cryphalus swezeyi Schedl, 1942: GUAM 1 1 ; Dededo; 11 May 1936; O. H. Swezey leg.; ex. Piper guahamense; label not transcribed or photographed; UFFE:14929; (NHMW)・ 1 I Paralectotype; Yigo, Ritidian pt.; 15 Apr. 1936; H. H Bryan leg.; ex. "ferns" [probably from beating ferns]; UFFE:26228; (NHMUK) • 1 + Paralectotype; Yigo; 18 Oct. 1936; O. H. Swezey leg.; ex. Ficus; ex. dead small leaved Ficus; UFFE:10416; (NHMUK) • 1 $\$ Paralectotype; Dededo; 11 May 1936; O. H. Swezey leg.; ex. Piper guahamense; label not transcribed or photographed; UFFE:14930; (NHMW).

Other material examined. NORTHERN MARIANA ISLANDS • 1; Saipan Island, Tuturam, Laulau Bay; 21 Jan. 1945; Henry S. Dybas leg.; Under bark; "Lot 560"; UFFE:12204; (USNM) • 1; Same collection data; UFFE:12205; (NMNH).

Discussion. Cryphalus swezeyi was described from specimens from Guam. We examined four specimens from the type series. An additional specimen was supposedly deposited in Hawai'i i (Hawaiian Sugar Planters Association, Honolulu) but could not be located.

Wood (1960) synonymized this species with C. sylvicola, on the grounds that there were overlapping characters such as size and proportions, and assumed that this was the consequence of localized variation which had since been eroded away by hybridization. Schedl (1963a) disagreed with the synonymy, and maintained the species as valid in subsequent publications (e.g. Schedl 1979a: 248). Wood again synonymized the species with C. sylvicola (Wood 1989: 172), but did not provide any additional justification.

While they do share some characters, particularly the long interstrial bristles on the elytral disc becoming short, scale-like and curved posteriorly on the declivity, the weakly emarginated epistoma of the male, and the scale-like setae on the pronotum, they differ in the sculpturing of the male frons (C. sylvicola: median surface of frons slightly reticulate; C. swezeyi: median surface of frons with a large, glossy patch). There are also differences in size (C. sylvicola: $1.2-1.5 \mathrm{~mm}$; C. swezeyi: $1.5-1.6 \mathrm{~mm}$ ), and in the proportions (C. sylvicola: $2.1-2.3$ times as long as wide; C. swezeyi: 1.9 times as long as wide). 


\section{Key to Cryphalus of Hawai'i}

1 Setae on pronotal disc entirely hair-like, sometimes dagger-like, but always much longer than wide $\ldots \ldots \ldots \ldots \ldots 2$

- $\quad$ Setae on pronotal disc include scale-like setae, sometimes with longer setae intermixed. . . . . . . . . . . . . . . . 3

2 Male pronotal margin with a continuous ridge and pronotal slope with only very small, sparse asperities. Female with 4-6 serrations on apical margin, and evenly spaced asperities on the pronotal slope. Pronotal disc short, less than 1/5 pronotal length (viewed dorsally) (Fig. 4E). Frons with a small longitudinal keel in the lower median (Figs. 4C-D). Males have a weak transverse carina at upper level of frons, obscured by the pronotum in most specimens. Found in various fruits, especially Artocar-

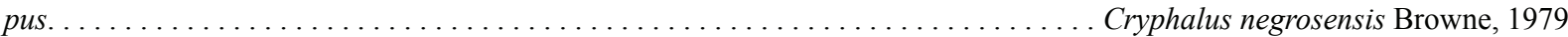
Both males and females with serrations on anterior margin, and asperities evenly spaced on pronotal slope. Pronotal disc longer, about $1 / 4$ the pronotal length (viewed dorsally). Frons with only minute aciculations, but no obvious median keel (Fig. 3D-E). Male and female frons similar. Mostly known from under bark of mango . . . . . . . . Cryphalus mangiferae Stebbing, 1914 Interstrial setae on elytral disc all scale-like, rows of longer scale-like setae extending onto the declivity of similar size and shape. Lower half of male frons similar to females, without any distinctive sculpturing, except a minute longitudinal keel (Fig. $2 \mathrm{E}$ ), and male pronotum only slightly flattened with asperities slightly smaller than females. Posterior margin of abdominal ventrites with distinct rows of dagger-like setae . . . . . . . . . . . . . . Cryphalus brasiliensis Schedl, 1976 Interstrial setae on elytral disc include erect, hair-like setae, which are shorter and more scale-like, and curved posteriorly, on declivity. Males with emargination along the lower margin of the frons and flattened pronotal slope and only small asperities. Posterior margin of abdominal ventrites with indistinct rows of hair-like setae $\ldots \ldots \ldots \ldots \ldots \ldots \ldots \ldots \ldots \ldots$ More than 2.1 times as long as wide, usually less than $1.4 \mathrm{~mm}$ length. Male frons with surface texture of median area similar to rest of frons (Fig. 5C). Pronotal disc approx. 1/3 of pronotal length (viewed dorsally). Usually matures dark brown. . . . . . . Cryphalus sylvicola (Perkins, 1900) Less than 2.1 times as long as wide, usually greater than $1.4 \mathrm{~mm}$ total length. Male frons with a wide glossy patch in median surface (Fig. 6C). Pronotal disc approx. 1/4 of total length (viewed dorsally). Usually matures orange-brown. . . . . . . . . . Cryphalus trypanoides (Beeson, 1935)

\section{Conclusions}

The Cryphalus spp. in Hawai'i have clearly been overlooked, with few collections or published records. Most of the species present are widely distributed over the Pacific islands, and associated with breadfruit, Artocarpus altilis. Since we know plants and fruits were transported across the Pacific islands over centuries (Zerega et al. 2006), it is plausible that all of the species are non-native, and transported with Artocarpus and Mangifera. Most species were recorded at least 60 years ago or longer, with the species being apparently present before the scolytine fauna was understood.

Cryphalus negrosensis may be a more recent introduction, since it is now common and collected from a wide range of fruits, yet the earliest record only dates to 2010 . The potential for economic impacts of fruit-inhabiting bark beetles is unknown. The other species present in Hawai ${ }^{i} i$ were found under the bark of recently dead branches, often near the interface of living tissue, in which they may contribute to progressive expansion of necrotic tissue. Additionally, the distribution within the Hawaiian Islands is poorly understood, and this treatment enables better documentation of Cryphalus species.

\section{Acknowledgements}

Jim Boone at the Bernice P. Bishop Museum provided access to collection and photographs of the type of Cryphalus trypanoides. Janis N. Matsunaga, Hawai'i Department of Agriculture provided specimens. Curtis Ewing provided specimens and some ecological notes about $C$. negrosensis. Max Barclay provided access and loan of specimens from the NHMUK. Thomas H. Atkinson provided photos of type specimens held at USNM.

AJJ was supported by the USDA Forest Service, by the USDA Agricultural Research Service, and by the National Science Foundation. DH was supported by Hawai'i Department of Agriculture, USDA Agricultural Research Service, USDA-APHIS, and Hatch project HAW09041-H, administered by CTAHR.

\section{References}

Beaver, R.A. (1976) The biology of Samoan bark and ambrosia beetles (Coleoptera, Scolytidae and Platypodidae). Bulletin of 
Entomological Research, 65, 531-548.

https://doi.org/10.1017/S0007485300006210

Beaver, R.A. (1987) The bark and ambrosia beetles (Coleoptera: Scolytidae and Platypodidae) of Tonga. New Zealand Entomologist, 9, 64-70.

https://doi.org/10.1080/00779962.1987.9722496

Beaver, R.A. (1990) New records and new species of bark and ambrosia beetles from Thailand (Coleoptera: Scolytidae and Platypodidae). Deutsche Entomologische Zeitschrift, 37, 279-284. https://doi.org/10.1002/mmnd.19900370408

Beaver, R.A. (1991) New synonymy and taxonomic changes in Pacific Scolytidae (Coleoptera). Annalen des Naturhistorisches Museums in Wien, 92 (B), 87-97.

Beaver, R.A. \& Maddison, P.A. (1990) The bark and ambrosia beetles of the Cook Islands and Niue (Coleoptera: Scolytidae and Platypodidae). Journal of Natural History, 24, 1365-1375. https://doi.org/10.1080/00222939000770821

Beeson, C.F.C. (1935) Scolytidae of the Marquesas. Bulletin of the Bernice P. Bishop Museum, 142, 101-114.

Bernard, J., Ewing, C.P. \& Messing, R.H. (2018) The structure and phenology of non-native scolytine beetle communities in coffee plantations on Kaua'i. Insects, 9 (4), 123. https://doi.org/10.3390/insects9040123

Boyle, B., Hopkins, N., Lu, Z., Garay, J.A.R., Mozzherin, D., Rees, T., Matasci, N., Narro, M.L., Piel, W.H., Mckay, S.J. \& Lowry, S. (2013) The taxonomic name resolution service: an online tool for automated standardization of plant names. BMC bioinformatics, 14 (1), 1-15. https://doi.org/10.1186/1471-2105-14-16

Browne, F.G. (1970) Some Scolytidae and Platypodidae (Coleoptera) in the collection of the British Museum. Journal of Natural History, 4, 539-583. https://doi.org/10.1080/00222937000770511

Browne, F.G. (1979) Additions to the scolytid fauna (Coleoptera: Scolytidae) of the Philippines. Philippine Journal of Science, 106 (1977), 85-86.

Eggers, H. (1928) Ipidae (Coleoptera) da America do Sul. Archivos do Instituto Biologico de Defesa Agricola e Animal, 1, 83-99.

Eggers, H. (1931) Zur Synonymie der Borkenkäfer (Ipidae, Col.). Wiener Entomologische Zeitung, 47 (1930), $184-186$.

Hagedorn, M. (1910) Coleoptera. Fam. Ipidae. In: Wytsman, P.A.G. (Ed.), Genera Insectorum, 111, pp. 1-178 + pl. 1-14.

Hopkins, A.D. (1915) Classification of the Cryphalinae, with descriptions of new genera and species. United States Department of Agriculture, Report, 99, 1-75, pls. 1-4. https://doi.org/10.5962/bhl.title.65905

Hopkins, G.H.E. (1927) Pests of economic plants in Samoa and other island groups. Bulletin of Entomological Research, 18 (1), 23-32. https://doi.org/10.1017/S0007485300019647

Johnson, A.J., Knížek, M., Atkinson, T.H., Jordal, B.H., Ploetz, R.C. \& Hulcr, J. (2017) Resolution of a global mango and fig pest identity crisis. Insect Systematics and Diversity, 1 (2), 1-10. https://doi.org/10.1093/isd/ixx010

Johnson, A.J., Hulcr, J., Knížek, M., Atkinson, T.H., Mandelshtam, M.Y., Smith, S.M., Cognato, A.I., Park, S., Li, Y. \& Jordal, B.H. (2020a) Revision of the bark beetle genera within the former Cryphalini (Curculionidae: Scolytinae). Insect Systematics and Diversity, 4 (3), 1-81 https://doi.org/10.1093/isd/ixaa002

Johnson, A.J., Li, Y., Mandelshtam, M.Y., Park, S., Lin, C.S., Gao, L. \& Hulcr, J. (2020b) East Asian Cryphalus Erichson (Curculionidae, Scolytinae): new species, new synonymy and redescriptions of species. ZooKeys, 995, 15-66. https://doi.org/10.3897/zookeys.995.55981

Kalshoven, L.G.E. (1958) Studies on the biology of Indonesian Scolytoidea. 4. Data on the habits of Scolytidae. First part. Tijdschrift voor Entomologie, 101, 157-180, pls.1-7.

Nishida, G. (2002) Hawaiian terrestrial arthropod checklist. Fourth edition. Bishop Museum Technical Report, $22,1-313$.

Perkins, R.C.L. (1900) Coleoptera, II. Coleoptera Rhynchophora, Proterhinidae, Heteromera and Cioidae. In: Sharp, D. (Ed.), Fauna Hawaiiensis or the Zoology of the Sandwich (Hawaiian) Isles: Being Results of the Explorations instituted by the Joint Committee appointed by the Royal Society of London for Promoting Natural Knowledge and the British Association for the Advancement of Science. And carried on with the assistance of those Bodies and of the Trustees of the Bernice Pauahi Bishop Museum at Honolulu. Vol. 2. Part 3. Cambridge University Press, Cambridge, pp. 117-270, pls. VII-X.

Pullen, K.R., Jennings, D. \& Oberprieler, R.G. (2014) Annotated catalogue of Australian weevils (Coleoptera: Curculionoidea). Zootaxa, 3896, 1-481. https://doi.org/10.11646/zootaxa.3896.1.1

Rabaglia, R.J., Beaver, R.A., Johnson, A.J., Schmaedick, M.A. \& Smith, S.M. (2020) The bark and ambrosia beetles (Coleoptera: Curculionidae: Scolytinae and Platypodinae) of American Samoa. Zootaxa, 4808 (1), 171-195.

https://doi.org/10.11646/zootaxa.4808.1.11

Schedl, K.E. (1939) Malaysian Scolytidae and Platypodidae (IV). Journal of the Federated Malay States Museum, 18, 327- 
364.

Schedl, K.E. (1941) 77th Contribution to the morphology and taxonomy of the Scolytoidea. Proceedings of the Hawaiian Entomological Society, 11, 109-116.

Schedl, K.E. (1942) Insects of Guam, 1. Coleoptera: Barkbeetles of Guam. Bulletin of the Bernice P. Bishop Museum, 172 , 147-149.

Schedl, K.E. (1950) Fauna Fijiana (Scolytoidea). 94. Contribution to the morphology and taxonomy of the Scolytoidea. Occasional Papers of Bernice P. Bishop Museum, 20, 35-54.

Schedl, K.E. (1955) Borken- und Ambrosiakäfer aus dem pazifischen Raum. 150. Beitrag zur Morphologie und Systematik der Scolytoidea. Entomologische Arbeiten aus dem Museum G. Frey, 6, 277-310.

Schedl, K.E. (1958) Zur Synonymie der Borkenkäfer, II. 159. Beitrag zur Morphologie und Systematik der Scolytoidea. Tijdschrift voor Entomologie, 101, 141-155.

Schedl, K.E. (1963a) Zur Synonymie der Borkenkäfer, IX. 209. Beitrag zur Morphologie und Systematik der Scolytoidea. Entomologische Abhandlungen und Berichte aus dem Staatlichen Museum für Tierkunde in Dresden, 28 (6), 257-268.

Schedl, K.E. (1963b) Zur Synonymie der Borkenkäfer, XI. 215. Beitrag zur Morphologie und Systematik der Scolytoidea. Koleopterologische Rundschau, 40/41, 60-66.

Schedl, K.E. (1966) Check list of the Scolytidae and Platypodidae from the Philippine Islands 196 Contribution. Entomologische Abhandlungen aus dem Staatlichen Museum für Tierkunde in Dresden, 35, 1-122.

Schedl, K.E. (1976) Neotropische Scolytoidea, XIII. Entomologische Abhandlungen aus dem Staatlichen Museum für Tierkunde in Dresden, 41, 49-92.

Schedl, K.E. (1979a) Die Typen der Sammlung Schedl, Familie Scolytidae (Coleoptera). Stand 1.1.1976. 329. Beitrag zur Morphologie und Systematik der Scolytoidea. Kataloge der wissenschaftlichen Sammlungen des Naturhistorischen Museums in Wien, Entomologie, 3 (2), 5-271.

Schedl, K.E. (1979b) New records and new species of Scolytidae (Coleoptera) from the Pacific region. 340. Contribution to the morphology and taxonomy of the Scolytoidea. New Zealand Entomologist, 7, 102-106. https://doi.org/10.1080/00779962.1979.9722344

Stebbing, E.P. (1903) Notes on insect pests from the entomological section, Indian Museum. I. Insect pests of fruit trees. Indian Museum Notes, 6, 63-77.

Stebbing, E.P. (1914) Indian forest insects of economic importance. Eyre \& Spottiswoode, London, 648 pp. https://doi.org/10.5962/bhl.title.23135

Swezey, O.H. (1941) Notes on food-plant relations of Scolytidae and Platypodidae in the Hawaiian Islands. Proceedings of the Hawaiian Entomological Society, 11 (1), 117-130.

Swezey, O.H. (1954) Forest entomology in Hawaii: an annotated check-list of the insect faunas of the various components of the Hawaiian forests. Special Publication of the Bernice P. Bishop Museum, 44, 1-266.

Tubbs, P. (1986). Hypocryphalus mangiferae (Stebbing, 1914) given nomenclatural precedence over Cryphalus inops Eichhoff, 1872 and Hypothenemus griseus Blackburn, 1885 (Insecta, Coleoptera). Bulletin of Zoological Nomenclature, 43 (3), 245-246.

van Zwaluwenberg, R.H. (1956) New records of Scolytidae. Proceedings of the Hawaiian Entomological Society, $16,9$.

Wood, S.L. (1960) Insects of Micronesia. Coleoptera: Platypodidae and Scolytidae. Insects of Micronesia, 18 (1), 1-73.

Wood, S.L. (1982) The bark and ambrosia beetles of North and Central America (Coleoptera: Scolytidae), a taxonomic monograph. The Great Basin Naturalist Memoirs, 6, 1-1359.

Wood, S.L. (1986) A reclassification of the genera of Scolytidae (Coleoptera). The Great Basin Naturalist Memoirs, 10, 1126.

Wood, S.L. (1989) Nomenclatural changes and new species of Scolytidae (Coleoptera), part IV. The Great Basin Naturalist, 49 (2), 167-185. https://doi.org/10.5962/bhl.part.22642

Wood, S.L. \& Bright, D.E. (1992) A catalog of Scolytidae and Platypodidae (Coleoptera), Part 2: Taxonomic Index. Great Basin Naturalist Memoirs, 13, 1-1553.

Zerega, N., Ragone, D. \& Motley, T.J. (2006) 10. Breadfruit Origins, Diversity, and Human-Facilitated Distribution. In: Motley, T J., Zerega, N. \& Cross, H. (Eds.), Darwin's Harvest. Columbia University Press, New York. pp. 213-238.

https://doi.org/10.7312/motl13316-011 